\title{
Vegetation Trends within Rest-Rotation and Season-long Grazing Systems in the Missouri River Breaks, Montana
}

\author{
C.R. WATTS, L.C. EICHHORN, AND R.J. MACKIE
}

\section{Abstract}

Trends in canopy-coverage of vegetation and bare ground were measured inside and outside exclosures on recent burns within three-pasture rest-rotation and season-long grazing systems over a 10-year period. Results suggested that rest-rotation grazing may maintain vegetation and soil cover somewhat comparable to ungrazed cattle exclosures on rough breaks-type range in northcentral Montana. Season-long grazing may not maintain satisfactory vegetation and soil cover in the area.

\section{Key Words: canopy-coverage, exclosures, cattle grazing}

Rest-rotation grazing (Hormay and Talbot 1961, Hormay 1970) has replaced continuous, season-long grazing on some Montana rangelands as a "tool" to improve vegetation composition, cover, and productivity. Although range condition can be maintained under season-long grazing with proper rates of use, it is difficult to improve a range with that type of management (Jefferies 1970). Willard and Herman (1977) reported that “...in eastern Montana...restrotation grazing allowed for better vigor of key forage species, faster soil water infiltration, more litter on the ground surface, reduced amounts of Opuntia polycantha, and greater production of desirable grasses." Conversely, seasonlong grazing resulted in lower plant vigor, slower soil water infiltration, less litter, less production of desirable grasses, and more Opuntia polycantha. Also, Ross (1973) stated that rest-rotation grazing with proper stocking may be the quickest way to improve Montana ranges.

Hormay (1970) indicated that rest-rotation grazing is applicable to essentially all rangeland and can serve to meet a wide variety of range, livestock, wildlife, and other resource management objectives. Such broad application has not been documented, however, and other authorities believe that regional or local conditions may influence both the use and the effects of the system. Jefferies (1970) reported that, in Montana, rest-rotation generally works well on bunchgrass ranges in poor to fair condition, but is not easily applied to areas of dissimilar vegetation and topography. Wambolt (1973) also indicated that no single grazing system is best under all conditions; therefore, each must be tested to determine which conditions it is best suited for (Willard and Herman 1977).

This paper reports the results of two 10-year (1971-1980) studies of vegetation trends on rough "breaks-type" rangeland adjacent to the Missouri River in northcentral Montana. One was designed to help evaluate the potential application of rest-rotation grazing in this area of diverse vegetation and topography. The second, within a dissimilar breaks area, was designed to evaluate season-long grazing under stocking rates considered proper.

\section{Study Areas and Methods}

The study areas were located south of the Missouri River in northeast Fergus and northwest Petroleum Counties, Montana. Topography, vegetation, climate, and land use of the Missouri Breaks have been described by Mackie (1970).

The "breaks" can be characterized as highly dissected uplands, frequently interspersed with deep coulees and creek bottoms. Big sagebrush (Artemisia tridentata Nutt.) and wheatgrasses (Agro-

\footnotetext{
Authors are fish and wildlife biologist, Montana Department of Fish, Wildlife, and Parks, 1509 West Washington, Lewistown 59457; wildlife biologist, USDI Bureau of Land Management, Lewistown, Mont. 59457; and professor of wildlife management, Department of Biology, Montana State University, Bozeman 59717 Manuscript accepted 31 March 1987.
}

pyron spp.) dominate the vegetation of ridgetops, while ponderosa pine (Pinus ponderosa Laws), Douglas fir (Psuedotsuga menziesii Mirb.), and Rocky Mountain juniper (Juniperus scopulorum Sarg.) are typical dominants on side slopes of drainages. Dominant grasses across the area include bluebunch wheatgrass ( $A$. spicatum Pursh), western whcatgrass (A. smithii Rydb.), green needlegrass (Stipa viridula Trin.), Sandberg bluegrass (Poa sandbergii Vasey), and prairie junegrass (Koeleria pyramidata (Lam.) Beauv.). Other dominant plants are sedges (Carex spp.), bastard toadflax (Comandra umbellata Nutt.), salsify (Tragopogon dubius Scop.), American vetch (Vicia americana Muhl.), snowberry (Symphoricarpos spp.), rose (Rosa spp.), fragrant sumac (Rhus aromatica Ait., rabbitbrush (Chrysothamnus spp.), and chokecherry (Prunus virginiana L.).

Soils in the breaks, derived from the underlying Bearpaw formation, are moderately saline and alkaline clays. Heavy clay loams of the Lisam-Thebo series predominant (USDA 1971). Elevations range from $700 \mathrm{~m}$ along the Missouri River to $1,100 \mathrm{~m}$ on the plateau. Average precipitation for the past 15 years was $37 \mathrm{~cm}$, most of which fell as rain during late spring. Annual precipitation varied from 19.7 to $63.8 \mathrm{~cm}$ during the period of study (Fig. 1).

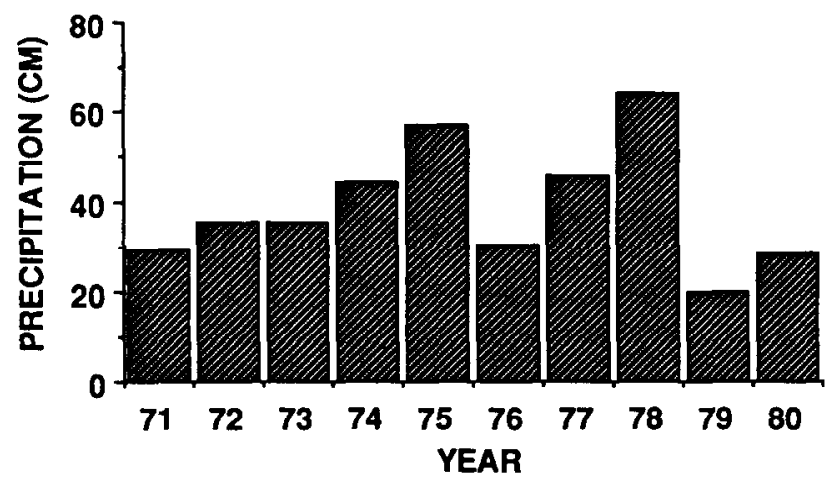

Fig. 1. Annual precipitation (cm) near the study areas, 1971-1980.

Vegetation trends associated with rest-rotation grazing were measured on 1 of 3 pastures in an 8,404-ha system established in 1969. The system was grazed by cattle following a formula that included: (1) early use from 15 May to 15 August; (2) late use from 15 August to 15 November; and (3) total rest. Livestock allotments for the 3 pastures totalled 3,482 AUMs, of which approximately $2,700(77 \%)$ were used annually. During the study, range condition rated fair to good across the allotment (unpubl. Iverson Allotment Management Plan, BLM, Lewistown, Mont.). The season-long system comprised 4,963 ha and was grazed by cattle annually from 15 May through 31 October. The allotment was 1,876 AUMs, which approximated annual use. Range condition during the study rated poor to fair (unpubl. Woodhawk Allotment Mangement Plan, BLM, Lewistown, Mont.).

The studies were conducted on recent wildfire burns in both pastures. We focused on these sites because wildfires are a common occurrence in the breaks, where old burns occur extensively, and we believe that burns might provide the opportunity to detect changes due to grazing in less time than studies on unburned areas. 
Eichhorn and Watts (1984) found rapid change in vegetation during early succession following wildfire in the breaks. Also, variables associated with prior grazing might be lessened or negated by studying recently burned areas.

Vegetation trends were assessed using exclosures (Jones 1965, McMahon 1966, Tueller and Tower 1979) and paired line transects. A 1-ha cattle exclosure, located to sample 3 major vegetation types, was established on the rest-rotation area in 1971. The types represented the Pinus ponderosa-Agropyron spicatum (PipoAgsp) association, the Pinus ponderosa-Juniperus scopulorum (Pipo-Jusc) association, and the Xanthium strumarium (Xast) association described by Mackie (1970). Three pairs of 30.5-m line transects, one member located inside the exclosure, the other on a closely comparable site of the same type outside the exclosure, were measured annually from 1971 through 1980 .

A 0.5-ha exclosure and 3 pairs of line transects were similarly established within the season-long unit in 1971-1972. These sampled the Artemisia tridenta-Agropyron smithii (Artr-Agsm) association, the Pinus ponderosa-Juniperus scopulorum association, and the Psuedotsuga menziesii-Juniperus scopulorum (PsmeJusc) association. The transects on Artr-Agsm were the first measured in 1971, those on Pipo-Jusc and Psme-Jusc in 1972. All were remeasured in 1974 and alternate years through 1980.

At the peak of vegetation growth in late June, we systematically located twenty, $2 \times 5$-dm plots at equal distance along each permanently marked transect line at each site. Canopy coverage was estimated for each plant species and forage class (grass/grass-like, forb, and shrub) as well as for bare ground and litter in each plot following Daubenmire (1959). Yellow sweetclover (Melilotus officinalis [L.] Lam.) was not included in analysis of forbs because of large moisture-related fluctuations in occurrence on the area.

Statistical procedures followed Snedecor and Cochran (1967). Tests for differences in independent values in single years were by $t$-test. For analyzing trends over the 10 years, we compared the apparent linear portions for likeness by regression whereby the F-test compares slope and level. Null hypotheses were rejected at $P<0.05$.

\section{Results}

\section{Vegetation Trends under Rest-Rotation Grazing \\ Grass}

With few exceptions, trends in grass coverage were similar between paired transects inside and outside exclosures on the 3 vegetation types (Fig. 2). After 10 years, there were no statistical differences in either slope or level of regression lines for any type.

Trends in grass coverage among years and over the 10 years varied greatly between the 3 types. Most of this variation was related to site characteristics and factors other than grazing. The greatest variation occurred on the Pipo-Agsp and Xast types on which grasses were relatively abundant and vegetational structure and composition were little affected by burning in 1970 (Eichhorn and Watts 1984). Grass coverage on both of these types increased sharply for 2-4 years and then declined variably to year 10 , when it differed little from year 1 . In contrast, grass coverage on the Pipo-Jusc type, on which grasses were sparse until burning eliminated competing woody vegetation, remained very low for 3-4 years and then generally increased through year 10 . This increase was from less than to greater than the amount of grass coverage on a similar unburned site (Eichhorn and Watts 1984).

Grass coverage invariably decreased the year following late grazing on transects outside of the exclosure in both the Pipo-Jusc and Xast types. This may explain the significant difference in coverage between paired transects on the Xast type in year 4 . Other significant differences in grass coverage during individual years were the result of accidental occurrences such as flooding. More intensive sampling might have dampened the effect of this factor.

\section{Forbs}

Trends in forb coverage were similar on paired transects inside and outside the exclosure on the Pipo-Agsp and Pipo-Jusc types (Fig. 2). There were no statistical differences in slope or level of regression lines for forb coverage on transects in Pipo-Agsp through the 10 years and in Pipo-Jusc after the burning-related surge in forb growth peaked at year 4. Although differences in trends in forb coverage between paired transects on the Xast type also appeared to be minor (Fig. 2), slopes of regression lines were significantly different, indicating that forb coverage generally decreased outside the exclosure and/or increased inside. After year 5 , forb coverage was greater on transects inside than outside the exclosure on all 3 types. Some of the differences, including those on all 3 types in year 10, were significant. As with grasses, trends in forb coverage varied among the 3 vegetation types. Here, however, the greatest variation occurred on the severely burned Pipo-Jusc type where forb coverage increased dramatically from years 1 through 4 , before declining to levels approximating those on the other 2 types.

\section{Bare Ground}

Trends in percent bare ground were similar between paired transects on the Pipo-Agsp and Pipo-Jusc types (Fig. 2). There were no statistical differences in either slope or level of regression lines for either type through the 10 years. On the Xast type, the trends were similar inside and outside the exclosure only through year 5; thereafter, bare ground decreased inside and increased outside the exclosure. The comparison of regression lines indicated a significant difference in levels inside and outside the exclosure through the 10 years.

As was the case with grasses and forbs, the statistical ( $t$-test) differences which occurred in some years between paired transects on all 3 types are difficult to interpret. Those on the Pipo-Jusc type all occurred during years in which the pasture was rested, but 3 of the 4 involved more bare ground inside than outside the exclosure.

\section{Vegetation Trends under Season-long Grazing Grass}

Although 10-year trends varied somewhat among the 3 types (Fig. 3), grass coverage generally increased on transects inside the exclosure. Trends on grazed transects were more varied. In the Artr-Agsm type, grass coverage outside the exclosure changed little over the 10 years. In Pipo-Jusc, grass coverage increased sharply from year 2 to year 4 , but changed little thereafter. In the Psmi-Jusc type, which occupied a steeper-sloped and more mesic site with deeper soil, grass coverage on the grazed transect increased through year 6 and then decreased to year 10 . By year 6 , grass coverage was significantly greater on transects inside than outside the exclosure on the Artr-Agsm and Pipo-Jusc types; at year 10 , it was significantly greater inside the exclosure on all 3 types.

\section{Forbs}

With very minor exceptions, trends in forb coverage were similar between paired transects inside and outside the exclosure on all 3 types (Fig. 3). There were no significant differences in either slope or level of regression lines for trend between any of the pairs through the 10 years.

\section{Shrubs}

Prior burning eliminated big sagebrush and it did not return during the duration of study. Other shrubs, primarily snowberry (Symphoricarpos spp.) and rose (Rosa sp.), occurred only in the Psme-Jusc and Pipo-Jusc types. Trends in shrub coverage were closely similar on transects inside and outside the exclosure in the Psme-Jusc type, and regression lines for trend through the 10 years were not significantly different in either slope or level. In PipoJusc, shrub coverage did not change on the grazed transect but increased gradually in the exclosure to a significant difference by year 8. Regression lines for trend through the 10 years were significantly different between transects. 

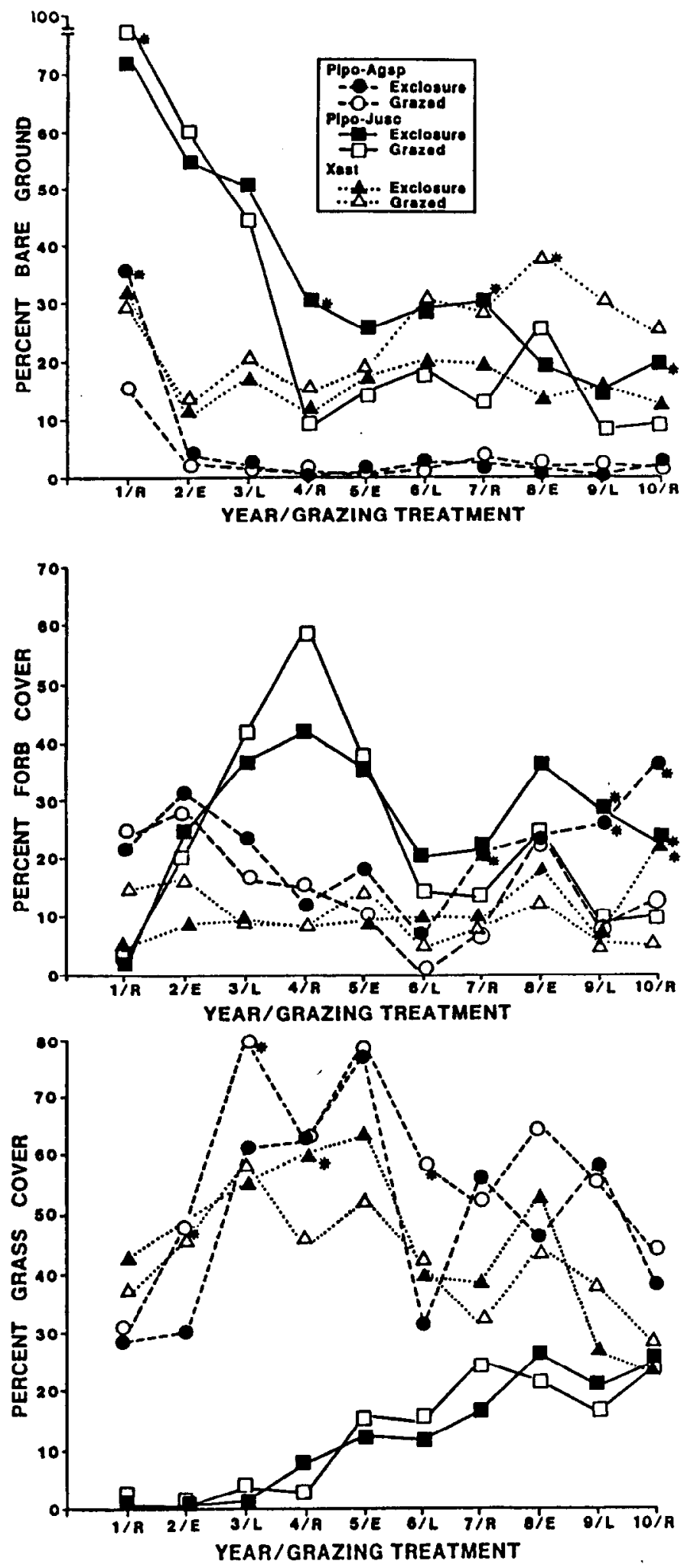

Fig. 2. Trends in coverage of grasses, forbs, and bare ground inside and outside an exclosure for 3 vegetation types in a 3-pasture rest-rotation grazing system on breaks-type range in Montana, 1971-1980. Livestock grazing treatments are $E=$ early use, $L=$ late use, and $R=$ rest. Asterisk $\left(^{*}\right)$ indicates significant difference $(P<0.05)$.
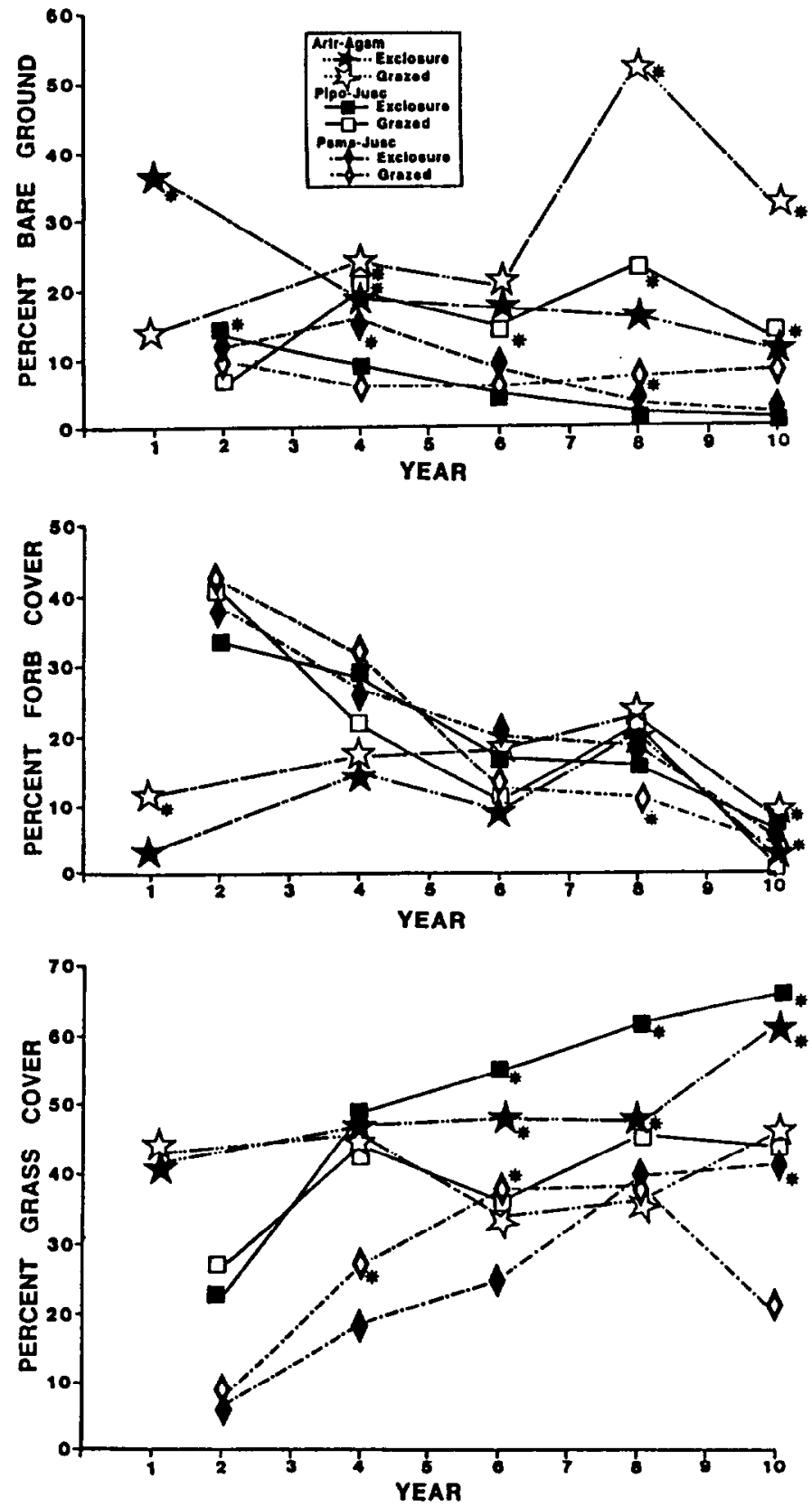

Fig. 3. Trends in coverage of grasses, forbs, and bare ground inside and outside an exclosure for 3 vegetation types in a season-long grazing system on breaks-type range in Montana, 1971-1980. Asterisk (*) indicates significant difference $(\mathrm{P}<0.05)$.

\section{Bare Ground}

The percentage of bare ground generally declined on transects inside the exclosure on all types through the 10 years (Fig. 3 ). On grazed transects, trends varied from little or no change in the Psme-Jusc type to a marked increase in Artr-Agsm. Initially, in years 1 or 2, somewhat greater amounts of bare ground were recorded on exclosure transects in all types, especially Artr-Agsm. By year 8 , significantly more bare ground occurred on all grazed transects. Comparison of regression lines for trends through the 10 years indicated significant differences between paired transects on both the Artr-Agsm and Pipo-Jusc types.

Litter measurements on the transects followed almost exactly the same trend as bare ground, the percentage increasing on transects inside the exclosure and remaining stable or decreasing outside. Greater percentages of litter were recorded on transects inside 
the exclosure by year 2 in the Pipo-Jusc type, by year 4 in the Artr-Agsm type, and by year 8 in Psme-Jusc.

\section{Conclusions and Discussion}

Results of this study suggest that rest-rotation grazing might maintain vegetation cover and trend comparable to that expected from elimination of cattle grazing on breaks-type range in northcentral Montana. Vegetation trends, as measured by coverage of grasses, forbs, and bare ground, under rest-rotation grazing were essentially the same as under complete protection from grazing. Total grass coverage and trends did not differ significantly between paired grazed and ungrazed transects on 3 vegetation types in the rest-rotation system over 10 years. In general, this was true also for trends in forb coverage and percent bare ground, where significant annual or 10-year differences occurred, and they were not necessarily related to or explained by grazing or protection from grazing.

These results should not be interpreted as providing evidence that rest-rotation grazing will lead to rapid or significant improvement in vegetative cover in the breaks. There were few, if any, significant changes in vegetation or ground cover over the 10 years that would indicate marked improvement attributable to treatment, either grazing or protection. Rather, major differences in trends between types, as compared with only minor differences between paired transects within types, would indicate that local site factors and conditions were overriding. The effects of fire were important, especially in trends on the severely burned Pipo- Jusc type where grasses and forbs developed only after burning eliminated the tree-shrub overstory, and coverage of these plants increased significantly through the 10 years. On the other 2 types, burning had much less effect, and grass and forb coverage fluctuated at levels comparable to that of unburned sites (Eichhorn and Watts 1984).

Trends under season-long grazing were very different from those associated with rest-rotation grazing. However, stocking rate was $18 \%$ higher under season-long grazing. There was far less similarity in vegetation and ground cover trends between paired transects through the 10 years. Grass coverage increased markedly under protection on all 3 types, while it either did not change or decreased on grazed transects. Shrub cover on the Pipo-Jusc type increased significantly under protection, but showed no change with continued grazing. Percentage of bare ground decreased as grass and litter increased on all ungrazed transects, while it increased or remained unchanged on grazed transects. These data would indicate that overall range trends were stable at best and may have declined on all 3 types under season-long grazing. In contrast, total protection appeared to result in significant improvement in range conditions, at least in terms of increased grass and ground cover during the period of study.

The trends under total protection, especially on the severely altered Pipo-Jusc and Psme-Jusc types were probably more a reflection of post-burning vegetational changes than a result of protection. A comparison of trends between the 2 study areas indicated that canopy-coverage levels and trends on both of those types were quite similar to those for the Pipo-Jusc type on the rest-rotation area at corresponding time periods after burning; i.e., years 2-6 for season-long and years 6-10 for rest-rotation. Similarly, coverage levels and trends for the less severely burned ArtrAgsm type showed relatively little change, which corresponded to trends on the lightly burned Xast and Pipo-Agsp types on the rest-rotation area.

The fact that canopy coverage of grasses and forbs remained stable or decreased and bare ground increased on grazed transects, while natural trends following burning and protection were the opposite, could be further indication that continuous season-long grazing will not maintain satisfactory vegetational conditions on breaks-type range. Thus, Jefferies' (1970) suggestion that seasonlong grazing with proper rates of use can maintain satisfactory range conditions may not apply. Either lower stocking rates than currently considered proper for the area or rest-rotation grazing might be necessary.

\section{Literature Cited}

Daubenmire, R.F. 1959. A canopy coverage method of vegetational analysis. Northwest Sci. 33:43-64.

Eichhorn, L.C., and C.R. Watts. 1984. Plant succession on burns in the river breaks of central Montana. Proc. Montana Acad. Sci. 43:21-34.

Hormay, A.L. 1970. Principles of rest-rotation grazing and multiple-use land management. USDI/BLM and USDA/FS Training Text (2200).

Hormay, A.L., and M.W. Talbot. 1961. Rest-rotation grazing ...a new management system for perennial bunchgrass ranges. USDA Forest Serv. Prod. Res. Rep. No. 51.

Jefferies, N.W. 1970. Planned grazing for Montana ranges. J. Range Manage. 23:373-376.

Jones, W.B. 1965. Response of major plant species to elk and cattle grazing in northwestern Wyoming. J. Range Manage. 18:218-220.

Mackie, R.J. 1970. Range ecology and relations of mule deer, elk, and cattle in the Missouri River Breaks, Montana. Wildl. Monogr. No. 20.

McMahon, C.A. 1966. Suitability of grazing exclosures for deer and livestock research in the Kerr Wildlife Management Area, Texas. J. Wildl. Manage. 30:151-162.

Ross, R.L. 1973. How to make grazing systems work. Cattlemen: The Beef Magazine. 36:20-21.

Snedecor, G.W., and W.G. Cochran. Ames, lowa. Sixth Edit. 593 p.

Tueller, P.T., and J.D. Tower.1979. Vegetation stagnation in three-phase big game exclosures. J. Range Manage. 32:258-263.

USDA. 1971. Soil survey of Crooked Creek Watershed Area-Petroleum County, Montana. Soil Conservtion Service, Lewistown.

Wambolt, C.L. 1973. Range grazing systems for resource conservation and greater production. Montana Coop. Ext. Serv. Bull. 340.

Willard, E.E., and L. Herman. 1977. Influence of grazing by various systems on vegetation and soils in the Missouri River Breaks area, Montana. Montana Forest and Conservation Exp. Sta., School of Forestry, Univ. Montana, Missoula. 